\title{
Length-Weight Relationship and Growth Parameters of Grey Mullets (Pisces: Mugilidae) in Two Estuaries in Ghana
}

\author{
R. Hederick Dankwa \\ CSIR-Water Research Institute, P.O. Box AH 38, Achimota, Ghana
}

\begin{abstract}
Grey mullet populations in the rivers Pra and Volta estuaries in Ghana were studied to provide information on their length-weight relationship and growth parameters. Fish samples were collected monthly for 18 months from local fishermen using cast net, drag net and gill nets. Six species of grey mullets were identified: sickle fin mullet, Liza falcipinnis (Valenciennes, 1836), large-scaled mullet, Liza grandisquamis (Valenciennes, 1836), grooved mullet, Liza dumerilii (Steindachner, 1870), white mullet, Mugil curema Vallenciennes, 1836, banana mullet, Mugil bananensis (Pellegrin, 1928) and striped mullet, Mugil cephalus Linnaeus, 1758. Length-weight relationship for the various species in the Volta and Pra estuaries, respectively, were: $L$. falcipinnis, $\mathrm{BW}=0.0158 \mathrm{SL}^{3.06}$ and $\mathrm{BW}=$ $0.0255 \mathrm{SL}^{2.85} ;$ L dumerillii, $\mathrm{BW}=0098 \mathrm{SL}^{3.24}$ and $\mathrm{BW}=0.0223 \mathrm{SL}^{2.92} ;$ M. bananensis, $\mathrm{BW}=0.0191 \mathrm{SL}^{3.03}$ and $\mathrm{BW}=$ $0.0175 \mathrm{SL}^{3.10} ;$ M. cephalus, $\mathrm{BW}=0.0574 \mathrm{SL}^{3.14}$ and $\mathrm{BW}=0.0134 \mathrm{SL}^{3.17} ;$ . curema, $\mathrm{BW}=0.0311 \mathrm{SL}^{2.85}$ and $\mathrm{BW}=$ $0.0247 \mathrm{SL}^{2.5}$. That for $L$. grandisquamis, which was found only in the Pra estuary, was $\mathrm{BW}=0.0204 \mathrm{SL}^{3.01}$, indicating isometric growth since the regression coefficient $b$ was not significantly different from $3.0(P>0.05)$. The regression coefficient $b$ for the other species was either significantly higher or lower than $3.0(P<0.01)$, suggesting allometric growth. Except $L$. dumerilli, $L \infty$ and $\mathrm{K}$ for the same species from the two estuaries differed. The highest $L \infty$ of $56.6 \mathrm{~cm}$ (SL) and growth performance index ( $\varnothing$ ) of 4.99 were estimated for M. cephalus. The $L \infty$ estimated in the study indicates that the sizes of grey mullets in the two estuaries were smaller compared to the same species from other countries in the tropics.
\end{abstract}

\section{Introduction}

Grey mullets comprise a large number of closely related species and belong to the family Mugilidae. They are successful teleost fishes which make up an important and probably the most widely distributed commercial fishes in the coastal waters of tropical and subtropical regions of the world (Wijeyaratne \& Costa, 1986; Koutrakis \& Sinis, 1994). In Ghana, grey mullets are important in the lagoon, estuarine and inshore fisheries along the entire coast.

Most of the studies done on grey mullets focused on their food and feeding habits (De Silva, 1980; Ferrari \& Chieregato, 1981; Ikomi, 1990; Blay, 1995ab; Dankwa et al., 2005). Not many studies have been conducted with respect to growth and lengthweight relationship of these species. The importance of growth parameters and length- weight relationships has been emphasised by various researchers (Sparre et al., 1989; Pauly, 1993; King, 1996; García-Arteaga et al., 1997). These include the determination of body size as a function of age, morphological comparisons between populations of the same species, or between species, apart from using it in the calculation of the fish's average weight at a certain length class, and conversion of an equation of growth in length into an equation of growth in weight.

Growth parameters of some grey mullet species in wetlands in north-eastern Greece have been reported by Koutrakis \& Sinis (1994), and from the Negombo Lagoon in Sri Lanka by Wijeyaratne \& Costa (1987). King (1996) reported the length-weight relationship of $M$. curema, M. cephalus and L. falcipinnis from the Nigerian coast, while Ikomi (1990) reported that for M. cephalus 
from the Niger Delta. The study sought to provide base line information on growth parameters and length-weight relationship of grey mullet populations in two estuaries in Ghana.

\section{Materials and methods}

Study sites

The study was conducted between February 1999 and July 2000 at the estuaries of River Pra and River Volta, both of which discharge into the Atlantic Ocean in the Gulf of Guinea. The two estuaries were chosen because of their location and the different ecological scenarios they offer (Fig. 1).

The River Volta estuary is located between latitudes $5^{\circ} 30^{\prime}$ and $6^{\circ} \mathrm{N}$ and longitudes $0^{\circ} 30^{\prime}$ and $1^{\circ} \mathrm{E}$ and lies within a coastal savanna zone that has an annual rainfall of between 750 and 1,250 $\mathrm{mm}$ (Dickson \& Benneh, 1988). The estuary was about $1,200 \mathrm{~m}$ wide at the mouth. Beyond the mouth of the estuary, the water body covers an extensive area with a number of islands most of which have human settlements.

The River Pra estuary is located between latitudes $5^{\circ}$ and $5^{\circ} 3^{\prime} \mathrm{N}$ and longitudes $1^{\circ} 30^{\prime}$ and $2^{\circ} \mathrm{W}$. The banks of the estuary are fringed by red mangroves (Rhizophora spp.) up to about $10 \mathrm{~km}$ inland (Obodai et al., 1996). The estuary was approximately $100 \mathrm{~m}$ wide at the point of entry into the sea. The basin lies in the moist evergreen forest zone of Ghana, with an annual rainfall of between 1,500 and 1,750 $\mathrm{mm}$ (Dickson \& Benneh, 1988) and is subjected to impacts of mining activities.

\section{Fish sampling and data analysis}

Grey mullets were sampled from the two estuaries with a set of nets; a cast net, a drag net and a battery of mono- and multi-filament gill nets. Samples were also bought from local fishermen to augment those caught from experimental fishing to ensure that the samples reflected, as much as possible, the population structure of grey mullets in the estuaries. They were kept in $10 \%$ formalin and sorted out into the various species in the laboratory using identification keys of Schneider (1990). The total length (TL) and standard length (SL) of individuals of the different species of fish were measured to the nearest $1.0 \mathrm{~cm}$, and the weight determined to the nearest $0.1 \mathrm{~g}$ using a measuring board and Sartorius balance, respectively.

The parameters $a$ (intercept) and $b$ (slope) of the length-weight relationship of the form $\mathrm{W}=\mathrm{aL}^{\mathrm{b}}$ were estimated for the different species through logarithmic transformation, i.e. $\log \mathrm{W}=\log a+b \log \mathrm{L}$, with $a$ and $b$ estimated by ordinary least squares regression. Differences in the slopes of the regressions, $b$, between same species from the two sites were evaluated using Student's $t$-test.

The growth of all the mullet species from the two estuaries was assumed to conform to the von Bertalanffy growth function (VBGF) which has the basic form:

$$
L_{t}=L \infty\left[1-\exp \left(-K\left(t-t_{o}\right)\right)\right]
$$

where $L_{t}$ is the length at age $t, L \infty$ is the asymptotic length, $K$ the growth constant and $t_{o}$ the theoretical age at length zero. The ELEFAN I programme, as incorporated in the FISAT software (Gayanilo et al., 1995), was used to fit growth curves to the restructured length frequency data. This was based on preliminary estimates of the asymptotic length $(L \infty)$ obtained using the method of Wetherall (1986), which is also incorporated in the FISAT programme. The value of the growth constant $K$ was obtained from the scanning routine in ELEFAN I. 


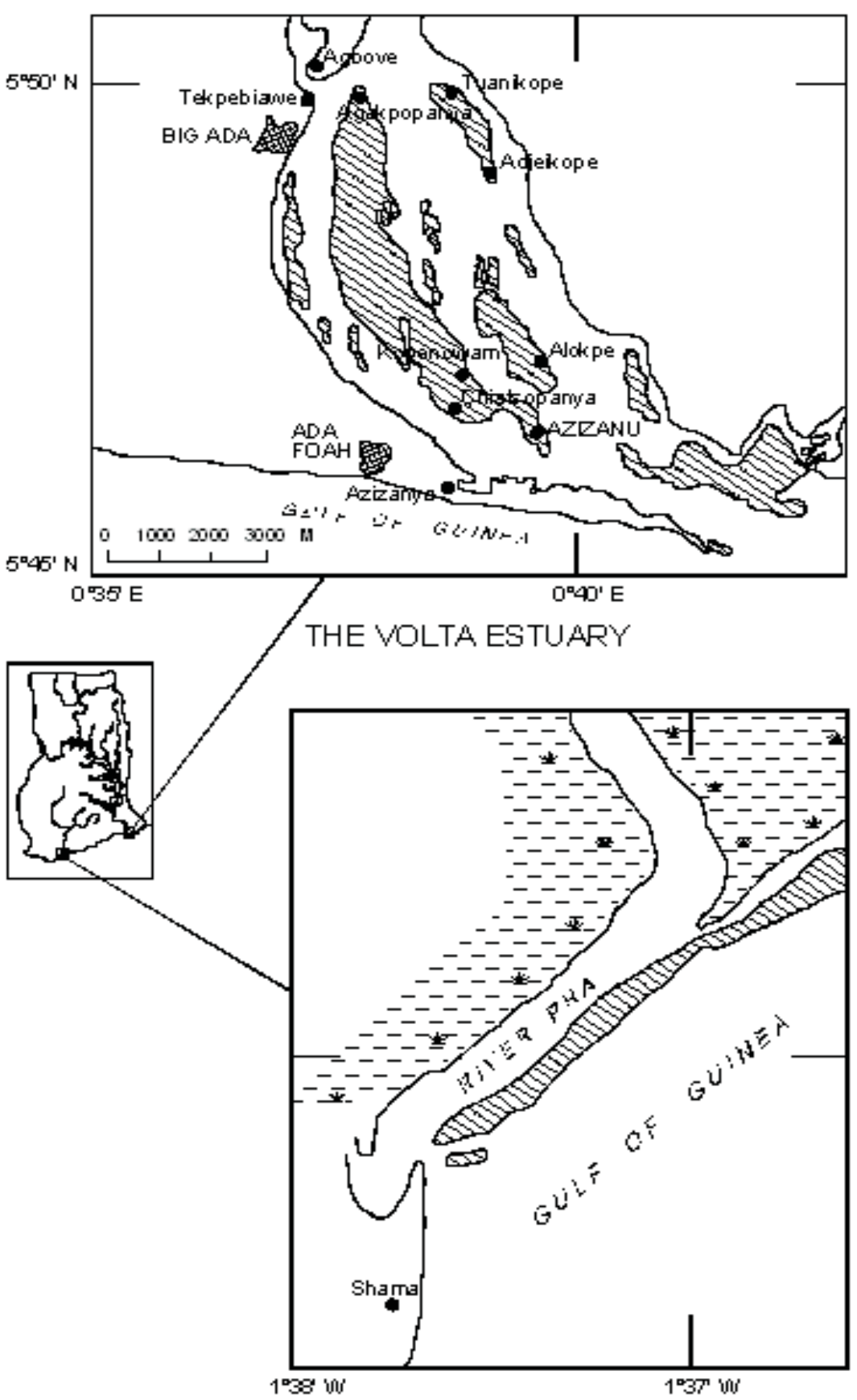

Fig. 1. Map showing the Volta and Pra estuaries 
The theoretical age at length zero $\left(t_{\circ}\right)$ was obtained from Pauly's (1979) equation:

$\log _{10}\left(-t_{o}\right)=-0.392-0.275 \log _{10} L \infty-$ $1.038 \log _{10} K$

The growth performance index $(\phi \square)$ was computed from the equation (Pauly \& Munro, 1984): $(\phi \square)=\log _{10} K+2 \log _{10} L \infty$

\section{Results}

Occurrence and size range of grey mullets caught

Six species of grey mullets and two genera, Liza and Mugil, were identified. The species were: sickle fin mullet, Liza falcipinnis (Valenciennes), large-scaled mullet, Liza grandiaquamis (Valenciennes), grooved mullet, Liza dumerilii (Staindachner), white mullet, Mugil curema Vallenciennes, banana mullet, Mugil bananensis (Pellegrin) and striped mullet, Mugil cephalus Linnaeus. With the exception of L. grandisquamis, which was found only in the Pra estuary, all the other species occurred in both estuaries.

The size range of the different species in the two estuaries is presented in Table 1.
Specimens of each species from the Volta were comparatively bigger than those from the Pra estuary.

The exponent $b$ or regression coefficient for a given species from the two estuaries was statistically different with the exception of $M$. cephalus (Table 2).

There was no significant difference between the regression coefficient $b$ for $L$. grandisquamis, and $3.0(P>0.05)$, indicating isometric growth while in the other species the exponent was either significantly higher or lower $(P<0.01)$ than 3.0 suggesting allometric growth.

\section{Growth parameters}

Fig. 2a shows estimation of growth parameters using Wetherall's method for $M$. bananensis from the Volta estuary, providing estimate of $L \infty$ as $20.5 \mathrm{~cm} \mathrm{SL}$. The corresponding estimate of $K$ was 0.78 year from the scan plot (Fig. 2b), and the growth curve superimposed on the restructured length-frequency data is shown in Fig. 3. A summary of the growth parameters $(K, L \infty$

TABLE 1

Size range of grey mullets caught in the Volta and Pra estuaries

\begin{tabular}{lllll}
\hline Species & \multicolumn{2}{c}{ Volta estuary } & \multicolumn{2}{c}{ Praestuary } \\
& $S L(\mathrm{~cm})$ & $W t(\mathrm{~g})$ & $S L(\mathrm{~cm})$ & $W t(\mathrm{~g})$ \\
\hline L. falcipinnis & $3.8-32.9$ & $1.1-262.3$ & $4.2-21.7$ & $1.3-205.6$ \\
L. dumerilii & $4.5-23.3$ & $1.6-216.3$ & $4.7-23.0$ & $2.3-238.7$ \\
L. grandisquamis & $\mathrm{NA}$ & $\mathrm{NA}$ & $7.0-16.3$ & $7.9-104.8$ \\
M. bananensis & $5.4-19.5$ & $3.6-174.5$ & $4.7-19.3$ & $2.1-153.2$ \\
M. curema & $5.4-27.0$ & $3.6-444.1$ & $5.0-15.8$ & $3.4-78.4$ \\
M. curema & $7.7-57.0$ & $10.2-3300$ & $11.5-35.5$ & $34.8-1250$ \\
\hline
\end{tabular}

NA- Not available 
TABLE 2

Parameters of length-weight relationship and coefficient of determination ( $r^{2}$ ) for grey mullet species from the Volta and Pra estuaries

\begin{tabular}{lllll}
\hline Species & Location & $a \pm S E$ & $b \pm S E$ & $r$ \\
\hline L. falcipinnis & Volta & $0.0158 \pm 0.002$ & $3.0561 \pm 0.02$ & 0.9928 \\
& Pra & $0.0255 \pm 0.005$ & $2.8507 \pm 0.05$ & 0.9500 \\
L. dumerilii & Volta & $0.0098 \pm 0.003$ & $3.2356 \pm 0.03$ & 0.9833 \\
& Pra & $0.0223 \pm 0.003$ & $2.9175 \pm 0.03$ & 0.9771 \\
L. grandisquamis & Volta & NC & NC & NC \\
& Pra & $0.0204 \pm 0.004$ & $3.0113 \pm 0.03$ & 0.9750 \\
M. bananensis & Volta & $0.0191 \pm 0.002$ & $3.0296 \pm 0.02$ & 0.9894 \\
M. curema & Pra & $0.0175 \pm 0.003$ & $3.1042 \pm 0.03$ & 0.9771 \\
M. cephalus & Volta & $0.0311 \pm 0.002$ & $2.8456 \pm 0.03$ & 0.9728 \\
& Pra & $0.0247 \pm 0.004$ & $2.9472 \pm 0.04$ & 0.9651 \\
& Volta & $0.0142 \pm 0.002$ & $3.1387 \pm 0.02 *$ & 0.9944 \\
& Pra & $0.0134 \pm 0.004$ & $3.1708 \pm 0.05 *$ & 0.9944 \\
\hline
\end{tabular}

* No significant difference between slopes at 5\% probability level. NC - Not caught.

and $\left.t_{o}\right)$ and growth performance $(\phi \square)$ is provided in Table 3 for all the species. A similar process was followed for the estimation of growth parameters for the other species from the two estuaries.

Apart from L. dumerilii whose $L \infty$ was similar in both estuaries, the $L \infty$ and $K$ for the other species from each estuary were different. Growth performance $(\phi \square)$ for the same species from both estuaries was, however, similar. The highest $L \infty$ in the Volta estuary was estimated for M. cephalus, while in the Pra estuary L. dumerilii had the highest estimate. It must be noted that no estimate was made for $M$. cephalus in the Pra estuary because of the small sample size.

\section{Discussion}

Growth of fish can be described as either allometric or isometric depending on the exponent $b$ (regression coefficient) of the length-weight relationship which is normally between 2.0 and 4.0. The value $b=3.0$ indicates that the fish grows symmetrically or isometrically while values other than 3.0 indicate allometric growth (Tesch, 1971). In isometric growth, the shape of the fish is maintained throughout life while aspects of the growth in populations that exhibit allometric growth may be out of proportion or the adults may appear different from the young ones (Tesch, 1971).

With the exception of L. grandisquamis from the Pra estuary, the exponent $b$ of the length-weight relationship of all the other species was significantly different from 3.0 an indication that grey mullets from the two estuaries exhibit allometric growth. A similar observation of allometric growth was made by King (1996) for M. curema, M. cephalus and L. falcipinnis on the Nigerian coast. $M$. cephalus from both estuaries exhibited 


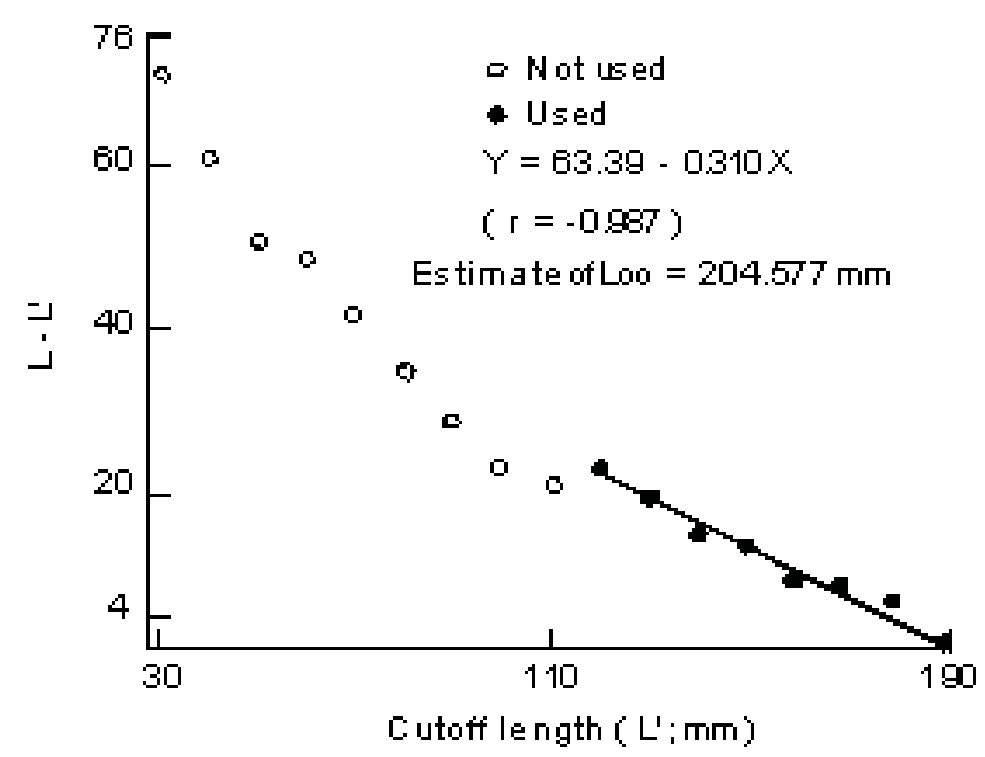

b

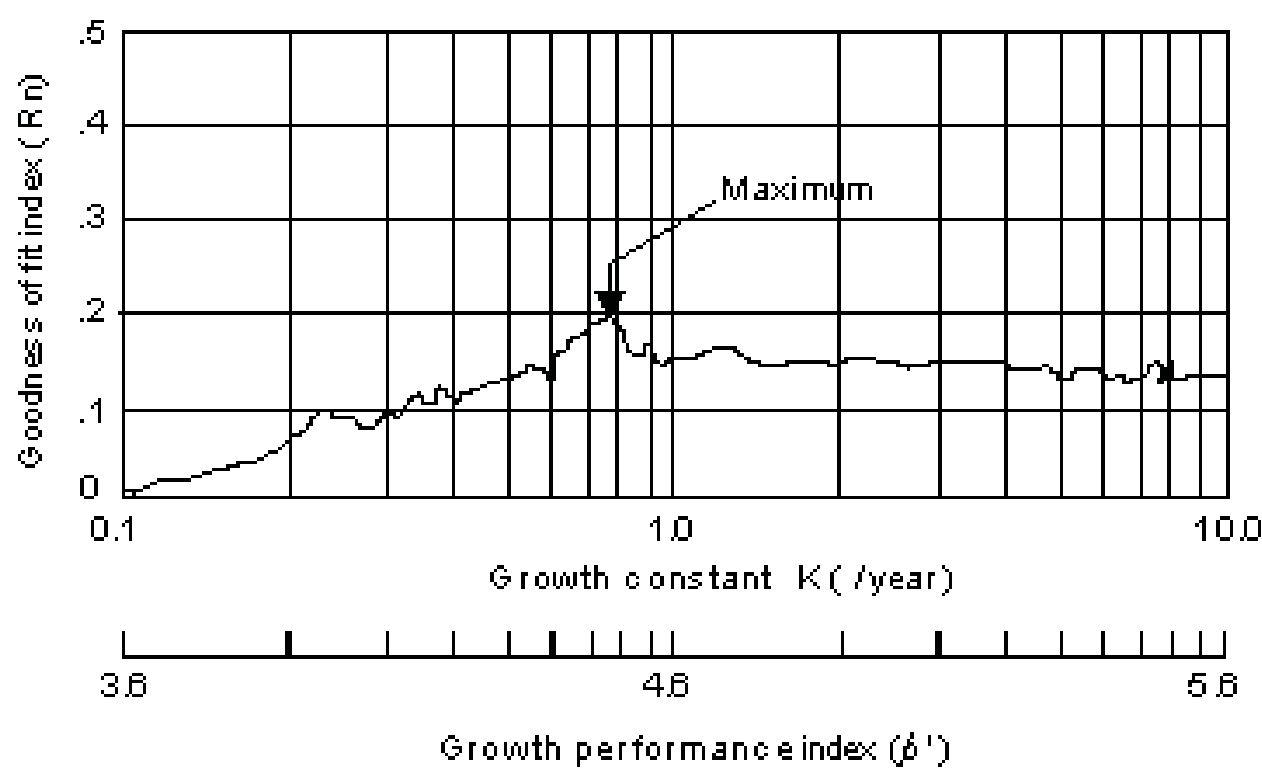

Fig. 2. Estimation of growth parameters - M. bananensis from the Volta estuary. Fig 2a - L $\infty$ from Wetherall plot; Fig. $2 b-K$ from the scan routine showing the location of 'best' estimate of $\mathrm{K}=0.78 \mathrm{yr}$ ' 


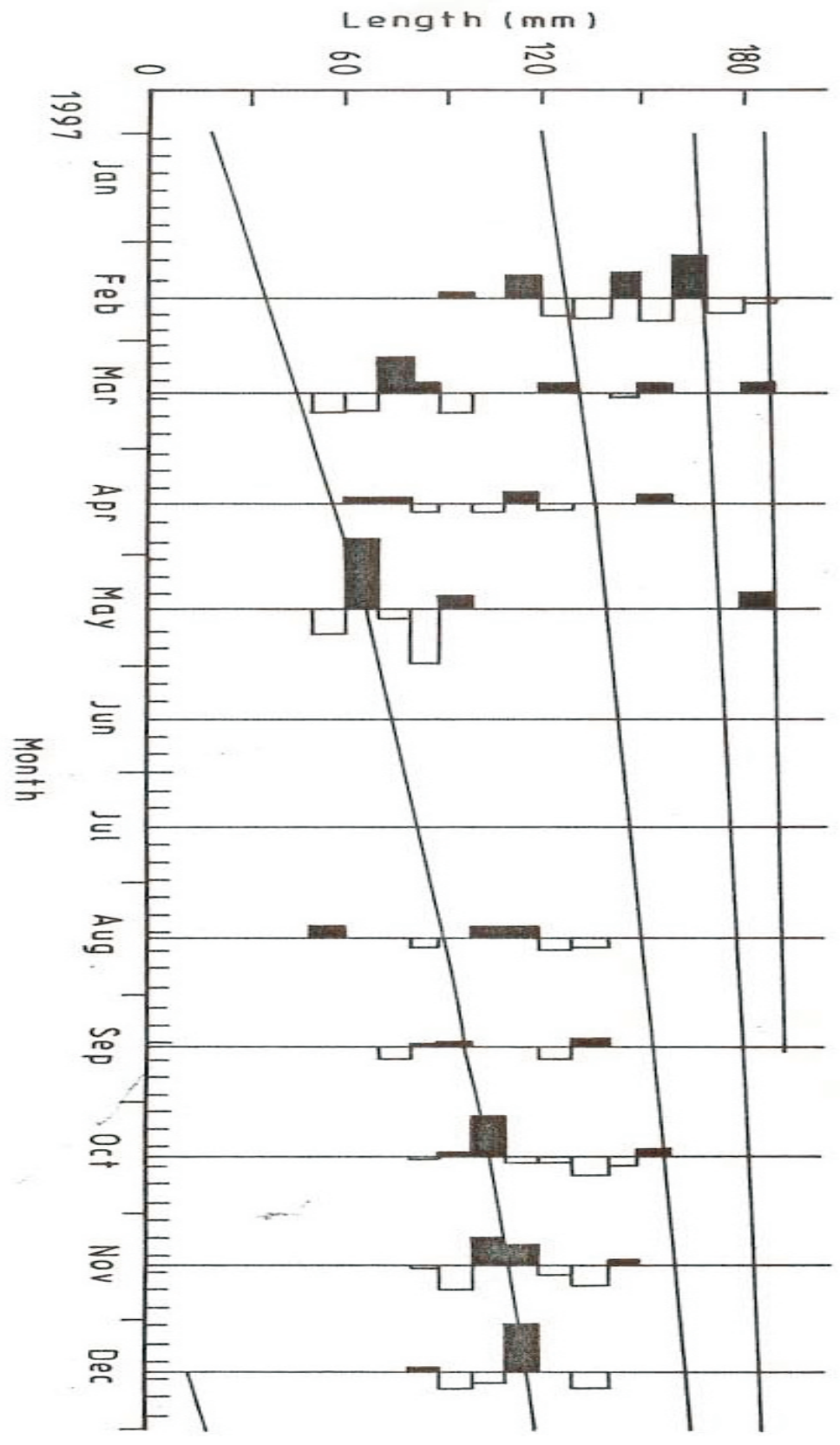

ig. 3. Restructured length-frequency data with superimposed growth curve for $M$. bananensis from the Volta estuary. $\left(L \infty=204.8 \mathrm{~mm} \mathrm{SL}, \mathrm{K}=0.78 \mathrm{yr}^{\prime}, \mathrm{t}_{\mathrm{o}}=-0.07\right.$ and $R n=0.159) \infty$ positive allometric growth, as reported for the species in the Niger Delta (Ikomi, 1990). The exponent $b$ differed significantly for the same species in the two estuaries, except for $M$. cephalus.

The dissimilarity in $b$ for a given species in the two estuaries indicates that the two habitats are different in terms of their impact on the shape of their fish populations. It is worth noting that the Pra estuary was more saline and turbid than the Volta estuary. Transparency ranged from 10 to $152 \mathrm{~cm}$ and 125 to $306 \mathrm{~cm}$ while salinity ranged from 0.07 to $16.0 \%$ and 0.06 to $8.17 \%$ in the Pra and Volta estuaries, respectively. Interpretation of the relationship of $M$. cephalus from the Pra estuary should, however, be treated with caution in view of the small sample size.

The growth parameters that were determined for the same species from the two estuaries were different. According to Sparre et al. (1989), growth parameters do not only differ from species to species but also among different populations of the same species. This may explain the different values obtained for the same species in each estuary. Apart from L. dumerilii from both estuaries whose $L \infty$ was similar, estimates for the species from the Volta estuary were relatively higher than those from the Pra estuary. All the species from the Volta estuary were comparatively larger than their counterparts from the Pra estuary. Fishing activities in and around the two estuaries were observed to be higher in the Pra than in the Volta estuary.

The preponderance of small-sized individuals in the samples from the Pra estuary could be an indication of overfishing which has, probably led to substantial reduction in the size of the species in that estuary. Apart from high fishing pressure it is 
TABLE 3

Growth parameters $\left(L \infty, K, t_{0}\right)$ and growth performance index $(\phi)$ of grey mullets from the Volta and Pra estuaries

\begin{tabular}{lllll}
\hline Species & $L \infty(S L, \mathrm{~cm})$ & $K\left(\right.$ year $\left.^{-1}\right)$ & $t_{o}($ years $)$ & $f$ \\
\hline Volta estuary & & & & \\
Lizafalcipinnis & 24.8 & 0.41 & -0.225 & 4.41 \\
Lizadumerilii & 23.3 & 0.55 & -0.169 & 4.50 \\
Mugil curema & 27.3 & 0.40 & -0.224 & 4.48 \\
Mugil bananensis & 20.5 & 0.78 & -0.122 & 4.51 \\
Mugil cephalus & 56.6 & 0.31 & -0.239 & 4.99 \\
& & & & \\
Pra estuary & & & -0.227 & 4.31 \\
Lizafalcipinnis & 22.0 & 0.42 & -0.223 & 4.60 \\
Lizadumerilii & 23.3 & 0.42 & -0.382 & 4.66 \\
Liza grandisquamis & 17.4 & 0.27 & -0.156 & 4.38 \\
Mugil curema & 19.6 & 0.62 & -0.308 & 4.09 \\
Mugil bananensis & 20.1 & 0.32 & & \\
\hline
\end{tabular}

also possible that low transparency in the Pra estuary due mainly to mining activities upstream could have adversely affected algal production and eventually growth of mullets. The growth performance index $(\phi \square)$ for the same species from both estuaries and among the various species was also similar except that of $M$. cephalus. This confirms the findings of Longhurst \& Pauly (1987) that the growth performance index $((\phi \square)$ is constant for a given species and similar within related groups of species.

$L \infty$ and $K$ of $M$. cephalus in the Negombo lagoon in Sri Lanka were $89.7 \mathrm{~cm}$ and 0.094 year', respectively (Wijeyeratne \& Costa, 1987). There are no estimates of growth parameters for the other species dealt with from previous studies; hence, no comparisons with populations from other areas could be made. However, specimens measuring $29.7 \mathrm{~cm}$ TL for $L$. grandisquamis, $41.0 \mathrm{~cm}$ TL for L. falcipinnis and $39.4 \mathrm{~cm} \mathrm{TL}$ for $M$. curema have been reported from the
Ébrié lagoon in Côte d'Ivoire (Alberet \& Legendre, 1985). The estimated theoretical maximum sizes for the species in the current study suggest that the sizes of grey mullets in the two estuaries were, generally, relatively small.

\section{Acknowledgement}

The author is grateful to the Agricultural Services Sub-sector Investment Project (AgSSIP) for funding the project out of which this study was made. His sincere thanks go to the CSIR-Water Research Institute for providing the necessary logistic support. He also thanks Mr Edem Amerdome and the late Mr Nicholas Anawoe for their assistance both in the field and in the laboratory.

\section{References}

Albaret J-J. and Legendre M. M. (1985). Biologie et ecologie des Mugilidae en lagune Ébrié (Côte d'Ivoire) Intérêt potentiel pour l'aquaculture lagunaire. Rev. d'Hydrobiol. Trop. 18(4): 281-304. 
Blay J. Jr (1995a.) Food and feeding habits of four species of juvenile mullets (Mugilidae) in a tidal lagoon in Ghana. J. Fish. Biol. 46: 134-141.

Blay J. Jr (1995b). Food habits and diel feeding periodicity of juvenile sickle-fin mullet, Liza falcipinnis (Pisces: Mugilidae), in a 'closed' tropical lagoon. Arch. Hydrobiol. 135(2): 271-281.

Dankwa H. R., Blay J. Jr and Yankson K. (2005). Food and feeding habits of grey mullets (Pisces: Mugilidae) in two estuaries in Ghana. West Afr. J. appl. Ecol. 8: 65-77.

De Silva S. S. (1980). Biology of juvenile grey mullets. A short review. Aquaculture 19: 21-36.

Dickson B. K. and Benneh G. (1988). A new geography of Ghana. Longman Group Ltd. U.K. $170 \mathrm{pp}$.

Ferrari I. and Chieregato A. R.. (1981). Feeding habits of juvenile stages of Sparus auratus L., Decentrahus labrax L. and Mugilidae in brackish embayment of the Po river delta. Aquaculture 25(2-3): 243-257.

Garcia-Arteaga J. P., Claro R. and Valle S. (1997). Length-weight relationships of Cuban Marine Fishes. Naga ICLARM Q. 20(1): 38-42.

Gayanilo Jr F. C., Sparre P. and Pauly D. (1995). The FAO-ICLARM stock assessment tools (FISAT) User's guide. FAO computerised information series: fisheries. ICLARM Contribution 1048. 126 pp.

Ikomi R. B. (1990). On the ecology of the grey mullet (Mugil cephalus L.) in the Kulama Creek (Niger Delta, Nigeria). Acta Hydrobiol. 32(1/2): 237-249.

King R. P. (1996). Length-weight relationships of Nigerian coastal water fishes. Naga ICLARM Q. 19(4): 53-58.

Koutrakis E. T. and Sinis A. I. (1994). Growth analysis of grey mullets (Pisces, Mugilidae) as related to age and site. Israel J. Zool. 40: 37-53.

Longhurst A. R. and Pauly D. (1987). Ecology of tropical oceans. Academic Press, Inc., New York. $507 \mathrm{pp}$.

Obodai E. A., Yankson K. and Blay J. Jr (1996). Seasonal changes in hydrographic factors and breeding in two populations of Crassostrea tulipa (Lamarck). Ghana J. Sci. 31-36 (1991-1996), 45-51.

Pauly D. (1993). Fish Byte Editorial. Naga ICLARM Q. 16(2/3): 26 .

Pauly D. (1979). Theory and management of tropical multispecies stocks: A review with emphasis on the Southeast Asian demersal fisheries. ICLARM Stud. Rev. 1:35.

Pauly D. and Munro J. L. (1984). Once more on the comparison of growth in fish and invertebrates. ICLARM FISHBYTE 2(1): 21.

Schneider W. (1990). Field guide to the commercial marine resources of the Gulf of Guinea. FAO, Rome. RAFR/FI/90/2.

Sparre P., Ursin E. and Venema S. C. (1989) Introduction to tropical fish stock assessment, Part I - Manual. FAO Fisheries Technical Paper 306/1. Rome. 337 pp.

Tesch F. W.. (1971). Age and growth. In Methods for assessment of fish production in fresh waters, 2nd edn. (W. E. Ricker, ed.), pp 98-130. Blackwell, Oxford.

Wetherall J. (1986). A new method for estimating growth and mortality parameters from lengthfrequency data. Fishbyte 4(10): 12-14.

Wijeyaratne M. J. S. and Costa H. H. (1987). The biology of grey mullets in a tropical lagoon in Sri Lanka. I. Age and growth. Bull.nat. Inst. Oceanog. 20: $163-170$.

Wijeyaratne M. J. S. and Costa, H. H. (1987). On the biology of an estuarine population of grey mullet, Mugil cephalus L. in Negambo lagoon, Sri Lanka. Cybium 10: 351-363. 